\title{
The Need for Corporate Risk Disclosure in the Nigerian Listed Companies Annual Reports
}

\author{
Musa Uba Adamu (B. Sc, M. Sc, PGDE)
}

\begin{abstract}
The study aims to elicit stakeholders' perceptions about the prospect attached to corporate risk disclosure in Nigeria. Recently, stakeholders' confidences were significantly affected by the recent financial crisis, sudden collapses of high profile companies across the globe and frequent management malpractices which are became order of the day. These were some of the incidents that have had caused current business environment to be very risky. Consequently, standard setters, academia, shareholders, professional bodies, and other stakeholders have advocated that, corporate entities should report risk related information in the content of their annual reports. Specifically, there were a lot of benefits are attached to this type of disclosure. Hence, to confirm the situation in Nigeria, the study employed survey method on which 300 questionnaires were administered to various stakeholders. The target respondents were financial analyst, stock brokers, bankers and shareholders. 230 questionnaires were successfully completed and returned. The results obtained have been analyzed by simple descriptive statistic. It is found that, corporate risk disclosure enhances corporate transparency; facilitates effective risk management; minimizes the problem of over/under stock valuation; and it also helps analyst to make earning forecast with reasonable accuracy. Therefore, it is concluded that providing risk related information in company's annual report is very important. As a result of that, Nigerian listed entities are urged to report risk related information due to derive all these benefits stated.
\end{abstract}

\section{Introduction}

The extent of risks that are inherited in the contemporary business environments required a lot of scholars, standard setters, accounting institutes, investors and other stakeholders from several countries to clamor for corporate risk disclosure in the content of listed companies' annual reports. Some of the factors responsible for these advocates include scandals perpetrated by corporate managers; accounting irregularities and the recent global financial crisis that have brought serious worrisome in the business world. These incidents caused the collapses of high profile companies across the globe, at the same time claimed the lives and properties of several stakeholders especially shareholders and creditors. These obstacles have also tempered with investors' confidences in the business world. However, at the turn of this century, Cabedo and Tirado (2004) argue that, current practice of companies' external reporting is considered as insufficient because is lacking an adequate disclosure on corporate risk and uncertainties. Therefore, there is need for the world regulators to address this disclosure demand. Nevertheless, perhaps, the demands of various regulators will create differences in the extent of corporate risk reporting between separate jurisdictions and between the firms listed on different stock exchanges across the globe. This gives rise to anticipation that companies listed in more than one country such as multinational corporations, most of the time are disclosing more about their risks than other companies' do, as they strive to meet the requirements of their most exciting regulators, in addition to any particular demands of the other regulators.

Based on the prior studies, a lot of countries have responded to risk disclosure demand by regulating it in their jurisdictions. Even though, vast number of studies concluded that current corporate risk disclosure practice is not adequate, therefore there is need for further improvement. Researches regarding corporate risk disclosure are becoming very common. For instance, Schrand and Elliott (1998); Deumes (1999); Beretta and Bozzolan (2004); Linsley and Lawrence (2006); Woods and Reber (2003); Fortin and Berthelot (2009); Rajab and Schachler (2009); Hossain (2008) explore different countries and examine the extent of corporate risk disclosure in entities' prospectus as well as the content of annual reports.

Nonetheless, all these studies were limited to the developed and semi developed countries. To the researcher's knowledge, research of this nature has not been conducted in Nigeria. Therefore, this study is aimed at eliciting stakeholders perceptions about the prospect attached to corporate risk disclosure in Nigeria. To achieve this aim, the paper is segregated into five sections. The theme has been introduced in the first section, relevant literature will be reviewed in the second section, section three will discuss the method employed in course of the study, the results will be analyzed and discussed in section four, and conclusion remarks will be considered in the final section 


\section{Literature Review \\ The Relevance of Corporate Risk Disclosure}

The scholars and authorities that are clamored for corporate risk reporting include: Deumes (1999); Jorion (2002); Fortin and Berthelot (2009); Linsmeir et al. (2002); Venkatachalan (1996); Linsmeier \& Pearson, (1997); Rajgopal (1999); The American Institute of Certified Public Accountants (AICPA, 1987); Companies Act (1985); ASB (1993\&2003); The Institute of Chartered Accountants in England and Wales (ICAEW); the International Accounting Standards Board (IASB); Financial Stability Board (2011).

The American Institute of Certified Public Accountants (AICPA, 1987) states that, the users of financial statements are desperately demanding for sufficient information disclosures that will help them to assess corporate risk and uncertainties accordingly (Rajab and Schachler, 2009). Add that, in U.K, the Companies Act, 1985 requires companies for a description of the principal risks and uncertainties that companies' faces in a business review; the disclosures shall be discussed as part of the Directors' Report in the content of companies' annual reports (Companies Act 1985, S.234). Nonetheless, in Nigeria, the Companies and Allied Matters Act (CAMA) 90 had been amended, but all the sections and subsections have failed to make a similar business review provision that will capture risk disclosure under directors' report. Furthermore, there has been long extensive discussion and debate on the Operating and Financial Review (OFR) that was initially launched by ASB in 1993 (ASB, 1993), a decade after the first launching, the statements have been revised and issued in 2003 (ASB, 2003), suggesting all the UK listed companies to report risks and uncertainties in content of their annual reports. In a similar effort, the Nigeria Accounting Standard board (NASB) has developed a series of accounting standards, but none of the standard has implemented this similar recommendation to Nigerian companies.

In addition, another advocate can be evident from the Institute of Chartered Accountants in England and Wales (ICAEW, 1999), it demonstrated considerable interest about the subject matter; the institute released number of documents that will guide companies' directors to tactically identify, manage and measure their risk profile. Moreover, enhancing corporate disclosure by providing sufficient risk-related information has a potential bearing upon the corporate performance (Rajab and Schachler, 2009). However, the Nigerian constitution has recognized only two (2) accounting professional institutes, but neither the Institute of Chartered Accountant of Nigeria (ICAN), nor the Association of National Accountant of Nigeria (ANAN) had made similar efforts as that of their foreign counterpart. Moreover, Rajab and Handley-Schachler (2009) posit that, there has been a increasing perception that financial reporting standards advanced by several standard setters such as the International Accounting Standards Board (IASB) and the UK's Accounting Standards Board (ASB) or those developed from different civil law codes in the continental Europe fell short of meeting all the relevant information needs by all the stakeholders. This is because, a world is changing on daily basis, and new events can happen today and instantly outdate the existing requirements. Therefore, there is the need for a regular updating. However, recently, Financial Stability Board (2011) posits that company's especially financial institutions with substantial exposures to a structured credit product and certain others on and off balance sheet risk exposures provide additional risk disclosures, and identified leading practices in this regards.

Nevertheless, apart from the above proposition made, the scholars such as, Beattie and Pratt (2002); Solomon et al.(2000); ICAEW (1997\&1999); Schrand and Elliott (1998) note that, investors need for detailed information that will be used in assessing a company risk profile with a view to make informed decisions. The present corporate reporting practice signifies the existence of a reporting gap especially in the manner corporate entities are conveying the information to investors and other stakeholders, the information is not adequate to investors, hence can cause the problem of information asymmetry. This is occurring in the event management holds information and withholds it from shareholders and other stakeholders for certain reasons, especially commercial sensitivity and uncertainty about measurements (Rajab and Schachler, 2009). Moreover, the FSB (2011) suggests that shareholders, financial institutions and auditors should collaborate to develop principles and specific risk disclosures for key risks that would be most pertinent to the conditions of market and risk exposures at reporting periods in the future.

Fortin and Berthelot (2009); Linsmeir et al. (2002); Venkatachalan, (1996) specifically recommend on financial risk disclosure in Management Discussion and Analysis (henceforth, MD \& A) or elsewhere in the content of financial report. However, they discuss further there is no uniformity in the manner companies reporting the information both within and between different countries. The MD \& A sections are not available in some countries' annual reports including Nigeria. Moreover, financial risks are the most frequent risk reporting than operational and strategic type of risks. This is the most regular perhaps as is the focus of International Financial Reporting Standards (IFRS).

Further more, it is very important to consider the demand of different investors from several jurisdiction and regulators in various countries in determining the extent of corporate risk disclosure/reporting that can be found in annual reports. Culture, jurisdiction, education and recent history can all influence market demand for such risk information (Rajab and Schachler, 2009). There is the need for the world regulators to 
design a comprehensive framework on the nature of risk, type of information, location and a manner on which risk related information will be reported. By harmonizing the issue, uniformity will be achieved between different companies and different countries.

However, even without such demands, the demands of various regulators will create differences in the extent of corporate risk reporting between separate jurisdictions and between the firms listed on different stock exchanges across the globe. This gives rise to anticipation that companies listed in more than one country such as multinational corporations, most of the time are disclosing more about their risks than other companies' do, as they strive to meet the requirements of their most exciting regulators, in addition to any particular demands of the other regulators. For instance, Schrand and Elliott (1998); Deumes (1999); Beretta and Bozzolan (2004); Linsley and Lawrence (2006); Woods and Reber (2003); Fortin and Berthelot (2009); Rajab and Schachler (2009); Hossain (2008) explores different countries and examine the extent of corporate risk disclosure/reporting in entities' prospectus as well as the content of annual reports.

\subsection{Motivation and benefits of Corporate Risk Reporting}

There are lots of benefits that can be derived from corporate risk reporting as pointed out by several authors. For instance, Deumes (1999) argues that, corporate risk disclosure is very important because it can improve corporate transparency. Consequently the activities of the capital market can be boosted and increase the shareholders value. In addition to the above, if transparency is achieved by way of conveying adequate information to stakeholders, the relevance and reliability of accounting information in the part of stakeholder's decision will be enhanced. Corporate Transparency can increase and maintain investors' confidence; hence accurate stocks valuation can be achieved.

Transparency can eliminate the disparities between what investors perceive and expect from what the corporate management can deliver (Deumes, 1999). From the part of Hutton (2004) believes that providing inadequate disclosure means that managers have superior information to investors, who may not fully understand the accompanying risks and rewards of a firm's business. Additionally, Skinner (1994\&1997) suggests that, companies might appreciate the benefit associated with corporate risk reporting and understand that markets will penalize all companies that provide insufficient information relative to their peers. In a further remark, he posited that corporate risk disclosure ensuring corporate competitive advantage in attracting capital. However, corporate managers may fear litigation and reputation costs as a result of providing voluntary risk information to investors; there is the need for rules/regulation that can protect managers from unnecessary litigation due to corporate risk disclosure. Nonetheless, Hutton (2004) posits that, provision of adequate corporate risk disclosure will enable investors to incorporate such risk especially in course of valuing their investments; thereby reducing excess demand that can cause stock price to be critically higher than they would be especially in the event market had the information that is available to managers. However, communicating risk related information will improve corporate transparency; hence, the problem of information asymmetry can be resolved. In the views of Akerlof (1970); Murugesu and Santhapparaj (2010) state that if the problem of information asymmetry is not fully resolved between management and investors, consequently, capital markets could undervalue some good companies and overvalue some bad companies relative to the information made available to investors and other stakeholders. Moreover, accurate disclosure on corporate risks and uncertainties can prevent severe damage to the long-term health and reputation of a company that may otherwise result from overvalued corporate equities (Fuller \& Jensen, 2002; Deumes, 1999). In addition, less information asymmetry however, lowers the risk of investors in forecasting future payoffs from their investment (Barry and Brown 1985, 1986; Deumes and Knechel, 2008; Abrahamson and Amir, 1996; Li, 2006). It can also reduce the firm's cost of capital and increase company value (Healy and Palepu, 2001; Barry and Brown, 1985 \&1986; Lang and Lundholm, 1996; Hill and short, 2007). There would be a beneficial positive impact upon the cost of capital arising from enhancing the confidence of the providers of capital who would be reassured through the conveying of such risk information.

Nevertheless, if company is known to have disclosed corporate risk, there is tendency to come up with strong measures in managing the risk (Solomon, 2000). High quality corporate risk disclosures contribute to financial stability by providing investors and other stakeholders with a better understanding of company's risk exposures and risk management practices (FSD, 2011). It can be evident that various risk management approaches have evolved over time and corporate entities have learnt to use sophisticated techniques to quantify and manage risk effectively, consequently reducing the gap in internal risk management systems(Rajab and Handley-Schachler, 2009). The need to report on risks and risk control measures can lead to the improvement of internal information being collected on the risks that the company faces. And indeed, the need to assure that the risks identified are being managed, as shareholders hold directors to account for their risk management. Murugesu and Santhapparaj(2010) argue that, from shareholder's perspective, the corporate risk disclosure practices of a company must be able to relate the effectiveness of its risk management and control systems due to improve shareholder value. In supplementary, Oliveira et al (2011) note that, proving adequate corporate risk 
disclosure could enhance corporate stability. The role of forward-looking information in voluntary corporate disclosure has been associated with more accurate analysts' earnings forecasts (Barron, Kile, \& Keefe, 1999) and with more accurate share-price anticipation (Schleicher \& Walker, 1999; Beretta and Bozzolan, 2004). This is in line with signaling literature, which posits that if no information is released to the market, investors' uncertainties increases and hence the market value of companies decreases (Downes and Heinkel, 1982).

\subsection{Limitations of Corporate Risk Reporting}

Corporate risk reporting is not completely advantageous as risk disclosures can create negative effects to the companies in different ways. There are shortcomings associated with corporate risk reporting as observed by several scholars. For instance, Edwards and Smith (1996); Linsley and Shrives (2005); Tsakumis et al. (2006); Rajab and Handley-Schachler (2009); Linsley et al. (2006); Hill and Short (2007) posit that directors of the corporate entities are often reluctant to convey supplementary disclosure in their annual report, because competitors may opportune to use strategic information disclosed to their advantage. This can cause the imposition of a proprietary cost, consequently putting a company at a competitive disadvantage and impacted upon the company negatively. Therefore, a company has to trade off the positive and negative effects of corporate voluntary disclosure. This can only be relevant whereby the disclosure is on voluntary ground not mandated by any authority or regulation.

Moreover, the truth about corporate risk reporting can cause the stock price to crash seriously especially in the short run. Long horizon managers prefer current pain associated with short run price declining because is very slightly compared to that arising from colluding in myth telling (Fuller \& Jensen, 2002). Additionally, corporate risk disclosure is not a costless undertaking (Botosan, 1997) because, identifying and reporting timely and accurate corporate risk information consumes valuable management time. Secondly, managers may perceive that there is a serious cost imposed on the company from the part of competitors who exploit the information to the detriment of the risk-disclosing company. Thirdly, there is the possibility of litigation in connection with a corporate risk-disclosure that is why directors are often reluctant to report such kind of risks information as it is inherently unreliable and could leave them open to potential claims from investors and other stakeholders who have acted upon this information (Linsley, Shrives and Crumpton, 2006). Finally, companies may be afraid to set a corporate risk disclosures precedent they cannot stick to (Hutton, 2004;

\section{Methodology}

This study employed survey research design on which three hundred (300) questionnaires have been administered to stakeholders. These include shareholders, stockbrokers, investment analyst and bankers. Nonetheless, stock broking firms are one of the meeting points of vast number of stakeholders; hence, they were used as one of the mediums of administering the questionnaires to their respective clients. The questionnaires are structured in five (5) liker scales on which strongly agreed, agreed, undecided, disagreed and strongly disagreed are represented by 5,4,3,2 and 1 respectively. All the respondents were randomly selected. Fortunately enough, about 230 questionnaires were successfully completed and returned. The results have been analyzed by the used of simple descriptive statistics.

\section{Result And Discussion}

This section will present, analyze and discuss the results obtained from the questionnaires administered to stakeholders in Nigeria. Thus:

Table 4.1

\begin{tabular}{|l|l|l|l|l|l|l|}
\hline OUESTIONS TO RESPONDENTS & $\mathbf{A}=\mathbf{5}$ & $\mathbf{B}=\mathbf{4}$ & $\mathbf{C = 3}$ & $\mathbf{D}=\mathbf{2}$ & $\mathbf{E}=\mathbf{1}$ & $\mathbf{M E A N}$ \\
\hline $\begin{array}{l}\text { 1. Providing risk related information in company } \\
\text { annual report is very important. }\end{array}$ & 180 & 50 & 0 & 0 & 0 & 4.78 \\
\hline $\begin{array}{l}\text { 2. Corporate risk disclosure can motivate effective } \\
\text { risk management }\end{array}$ & 110 & 120 & 0 & 0 & 0 & 4.48 \\
\hline $\begin{array}{l}\text { 3. Corporate risk disclosure can enhance transparency } \\
\text { and attract foreign direct investment. }\end{array}$ & 60 & 150 & 20 & 0 & 0 & 4.17 \\
\hline $\begin{array}{l}\text { 4. Corporate risk disclosure can resolve the problem } \\
\text { of over/under stock valuation }\end{array}$ & 70 & 120 & 20 & 20 & 0 & 4.04 \\
\hline $\begin{array}{l}\text { 5. Corporate risk disclosure would be helpful in } \\
\text { discouraging management malpractice. }\end{array}$ & 70 & 70 & 40 & 30 & 20 & 3.61 \\
\hline $\begin{array}{l}\text { 6. Corporate risk disclosure can help firms to access } \\
\text { loan facilities on demand }\end{array}$ & 60 & 80 & 50 & 10 & 30 & 3.56 \\
\hline $\begin{array}{l}\text { 7. Corporate risk disclosure can help analyst to make } \\
\text { earning forecast with reasonable accuracy. }\end{array}$ & 70 & 150 & 10 & 0 & 0 & 4.26 \\
\hline
\end{tabular}




\begin{tabular}{|c|c|c|c|c|c|}
\hline $\begin{array}{l}\text { 8. Corporate risk disclosure can be helpful in } \\
\text { restoring investors' confidence as information will } \\
\text { provide good investment direction to less risky firms. }\end{array}$ & 60 & 100 & 70 & 0 & 0 \\
\hline $\begin{array}{l}\text { 9. If majority of firms report risk, the others that } \\
\text { failed will be penalized by the market as their stocks } \\
\text { will not be attractive to investors. }\end{array}$ & 60 & 60 & 90 & 0 & 20 \\
\hline $\begin{array}{l}\text { 10. The stakeholders would consider non disclosing } \\
\text { firms annual reports as inadequate. }\end{array}$ & 40 & 80 & 90 & 0 & 20 \\
\hline
\end{tabular}

\section{SOURCE: Survey, 2012.}

The result reveals that investors and other stakeholders have welcomed the idea of incorporating risk related information in the content of financial statements. This can be evident from the responses made by the respondents as depicted in Table 4.1. All the respondents have agreed with the importance of this kind of disclosure in Nigeria. The mean score the maximum figure of 4.78 as there is absence of any objection from the part of respondents.

There is no any doubt from the fact that when ever company identifies and discloses their risk to the general public inform of annual reports, they don't have any alternative apart from taken strong measures of handling the case to a tolerance level. This can be supported by the results portray in the table 4.1. The mean scores about 4.48, which implied that respondents have agreed to what is contained in that question 2 . This result support the prior findings of Rajab and Handley- Scheler (2009), Murugesu and Santhapparaj (2010) who argue that, from shareholder's perspective, the corporate risk disclosure practices of a company must be able to relate the effectiveness of its risk management and control systems due to improve shareholder value.

Table 4.1 under question 3 shows the mean of 4.17, this figure out weight the bench marks of agreeing figure of 3.00 . Over $90 \%$ of the respondents have agreed that risk disclosure can enhance corporate transparency. One can argue that, how can corporate entities report their secret to the open world? Yes, they have to report it to open world because that is what investors and other stakeholders required for absolute scrutiny prior to any decision making. There were several cases whereby high profile companies collapsed suddenly without any indication. These shareholders were the one that ranked higher in bearing the consequences. The result obtained is consistent with that of Deumes (1999) who argues that, corporate risk disclosure is very important because it can improve corporate transparency.

However, in respond to question 4, the mean scores 4.04, this figure indicates the possibilities of trading securities at fair prices as investors having some ideas about risk position of the company. Even though, the basis on which stock prices are moving in Nigeria is highly questionable. Bribery, inside dealings and other maneuvers from the part of some stakeholders can also be considered as one of the determining factors of stock price movement. This finding is in line with Barron, Kile, \& Keefe (1999); Schleicher \& Walker (1999); Beretta and Bozzolan, (2004) who posit that voluntary corporate disclosure has been associated with more accurate share-price anticipation.

Investors have no one to blame apart from legal provisions that restrained them from controlling their own business. Even though, there is no way on which all the investors can be part of controlling group. Consequently, managers were the one saddled with the responsibility of controlling corporate entity affairs. Despite their power, but a lot of cases were reported globally indicted managers in perpetrating corporate malpractice. Hence, some people were on the opinion that, if corporate risk disclosure is insisted, malpractice can be deterrent among the corporate managers. This can be witnessed from the mean score of 3.61 as shown in table 4.1 based on respond to the question 5 .

Moreover, it is very common for the financial institution to require any entity demands to obtain loan at least to produce a copy of their financial statement. This move would help them to assess company risk profile. Perhaps, if they satisfied with what is contained there, loan can be granted. Certainly on this ground, corporate risk disclosure can be helpful in facilitating loan facility, especially to less risky entity. This statement can be considered acceptable particularly by regarding the mean score of 3.56 as displayed in the table 4.1, under question 6. Nevertheless, some of the respondents argued that, connection is the most powerful driver of securing loan facility.

The future is uncertain. Hence, as analysts appreciate the risk level of an entity would make them to incorporate it in their earning forecast. The mean of the responses scores 4.26 as shown in the table on question 7. This value is worth to consider corporate risk disclosure as appropriate in Nigerian listed companies' annual reports. This supports the findings of Barron et al. (1999); Schleicher \& Walker (1999); Beretta and Bozzolan (2004) who state that, the role of forward-looking information in voluntary corporate disclosure has been associated with more accurate analysts' earnings forecasts and with more accurate share-price anticipation. 
This table 1 under question 8 reveals the mean score of 3.96. Significant numbers of investors have lost confidence in the market. Right from 2008 global financial crisis, investors were under critical condition as their investment is melting like ice cream. The way how some company share price shed value is extraneous to common man imagination. For example, prior to the incident, intercontinental bank and oceanic bank shares were traded for over \#45 each, but eventually were traded at less than \#1. At the same time some companies stock such as nestle, flourmills etc have regain the position. Therefore, if an entity will report their risk, certainly, investors can have their direction by running away from highly risky company, there by can be confident to invest in less risk firms.

The score of the mean in the table on question 9 is 3.61. In the situation where by majority of corporate entity communicate their risk position via financial statement, but other refused, of course, stakeholders may suspect those who denied the information for them. Where the suspecting became high, there is tendency for investors not to patronize their shares. Consequently, their price will fall drastically.

The mean value is 3.52 as depicted by table 10. All the stakeholders that were familiar with corporate risk disclosure in other part of the world can conclude that, any annual report that have not contained company risk position as not worthy for their assessment.

\section{Conclusion}

Recently, researchers have developed great interest about the issue of incorporating risk information in the content of entities annual reports. There were a lot of benefits that nave been identified in the literature with regards to corporate risk disclosures. There is tendency of identifying such kinds of benefits in Nigeria. That is why this study elicited some stakeholders' perceptions about this subject matter in Nigeria. On the basis of literature review, analysis and interpretation the study come up with the following findings: corporate risk disclosure enhances corporate transparency; facilitates effective risk management; minimizes the problem of over/under stock valuation; and it also helps analyst to make earning forecast with reasonable accuracy. Therefore, it is concluded that providing risk related information in company's annual report is very important. As a result of that, Nigerian listed entities are urged to report risk related information due to derive all these benefits stated.

\section{References:}

[1] Abrahamson, E. and Amir, E. (1996). The information content of the president's letter to shareholders. Journal of Business Finance and Accounting, /8, 1157-1182.

[2] AICPA (1987). Report of the Task Force on Risk and Uncertainties, American Institute of Certified Public Accountants, New York, NY.

[3] Akerlof, G. A. (1970). The Market for 'Lemons': Quality, Uncertainty and the Market Mechanism, Quarterly Journal of Economics. 84/3, 488-500

[4] ASB (1993). Reporting Statement: Operating and Financial Review, Accounting Standards Board, London.

[5] Barron, O. E., Kile, C. O., and Keefe, T. B. (1999). MD\&A quality as a measure by the SEC and analysts' earnings forecasts. Contemporary Accounting Research, 1/1, 75- 109

[6] Beretta, S. and Bozzolan, S. (2004). A framework for the analysis of firm risk communication, International Journal of Accounting, 39/. 265-288.

[7] Bliss, R. R. and Flannery, M. J. (2002). Market discipline in the government of US bank holding companies: Monitoring versus influencing. European Finance Review, 6/3, 361-395.

[8] Botosan, C. A. (1997). Disclosure level and the cost of equity capital. The Accounting Review, 72/3, 232-349.

[9] Cabedo, J. D. and Tirado, J. M. (2004). The disclosure of risk in financial Statements. Accounting Forum, 28/, 181-200.

[10] Deumes, R. (2008). Corporate risk reporting: A content analysis of narrative risk disclosures in prospectuses. The Journal of Business Communication, 45/2, 120-157.

[11] Deumes, R. and Knechel, W. R. (2008). Economic Incentives for Voluntary Reporting on Internal Risk Management and Control Systems. Auditing: A journal of practice \& theory 27/1, 35-66

[12] Fuller, J. and Jensen, M. C. (2002). Just say no to Wall Street. Journal of Applied Corporate Finance,14/4, 41-46.

[13] Hackston, D. and Milne, M. J. (1996). Some determinants of social and environmental disclosures in New Zealand companies. Accounting, Auditing and Accountability Journal, 9/1, 77-108.

[14] Hill, P. and Short, H. (2009). Risk disclosures on the second tier markets of the London Stock Exchange. Journal of Accounting and Finance, 49/, 753-780.

[15] Healy, P. M., \& Palepu, K. G. (1994). Voluntary corporate disclosure: Who, what, and why? Working Paper, MIT Sloan School of Management, Cambridge, MA.

[16] Hodder, L.; Koonce, L.; and McAnally, M.L., (2001). SEC market risk implications for judgement and decision making. Accounting Horizons, 15/1, 49-70.

[17] Hossain, M (2008). The Extent of Disclosure in Annual Reports of Banking Companies: The Case of India. European Journal of Scientific Research, 23/4, 659-680. http://www.eurojournals.com/ejsr.htm

[18] ICAEW (1997). Financial Reporting of Risk: Proposals for a Statement of Business Risk, Institute of Chartered Accountants in England and Wales, London.

[19] ICAEW (1999). No Surprise: The Case for Better Risk Reporting, Institute of Chartered Accountants in England and Wales, London.

[20] Jarion, P. (2002). How informative are value-at-risk disclosures? The Accounting Review, 77/4, $911-931$.

[21] Kaplan, R.S. and Norton, D. P. (1996). Balanced Scorecard: Translating Strategy into Action, Harvard Business School Press, Boston. 
[22] Lajili, K. and Zeghal, D. (2005). A Content Analysis of Risk Management Disclosures in Canadian Annual Reports. The Canadian Journal of Administrative Sciences, 22/2, 125-142

[23] Linsley, P.M. and Lawrence, M. J (2006). Risk reporting by the largest UK companies: readability and lack of obfuscation. Accounting, Auditing \& Accountability Journal, 20/4, 620-627. Emerald Group Publishing Limited. www.emeraldinsight.com/0951-3574.htmLinsley, P. M., and Shrives, P. J. (2006).

[24] Risk reporting: a study of risk disclosures in the annual reports of UK companies. British Accounting Review, 38/, 387-404.

[25] Linsmeier, T.J., Pearson, N.D., (1997). Quantitative disclosures of market risk in the SEC release. Accounting Horizons, 11/1,107135.

[26] Linsmeier, T. J., Thornton, D. B., Venkatachalam, M., and Welker, M. (2002). The effect of mandated market risk disclosures on trading volume sensitivity to interest rate, exchange rate, and commodity price movements. The Accounting Review, 77/2, 343377.

[27] Murugesu, J. and Santhapparaj, A. S (2010). Impact of Risk Disclosure in the Prospectus on Valuation and Initial Returns of Initial Public Offerings in Malaysia. The IUP Journal of Applied Finance,16/6. 30-53

[28] Nier, E. and Baumann, U. (2004). Disclosure, volatility, and transparency: An empirical investigation into the value of bank disclosure. Federal Reserve Bank of New York. Economic Policy Review, 10/2, 31-45.

[29] Oliveira, J. Rodrigues, L. M. and Craig, R. (2011). Risk-related disclosure practices in the annual reports of Portuguese credit institutions: An exploratory study. Journal of Banking Regulation,12/2, 100-118.

[30] Rajab, B. and Handley-Schachler, M. (2009). Corporate risk disclosure by UK firms: Trends and determinants. World Review of Entrepreneurship Management and Sustainable Development, 5/3, 224-243.

[31] Rajgopal, S. (1999). Early evidence on the informativeness of the SEC's market risk disclosures: The case of commodity price risk exposure of oil and gas producers. Accounting Review, 74/3, 251-280.

[32] Schrand, C.M. and Elliott, J. (1998). Risk and financial reporting, a summary of the discussion at the 1997 AAA/ FASB conference, Accounting Horizons, 12/3, 271-283.

[33] Sensarma, R. and Jayadev, M. (2009). Are bank stocks sensitive to Risk Management? The Journal of Risk Finance, 10/1, 7-22.

[34] Skinner, D. (1994). Why firms voluntarily disclose bad news. Journal of Accounting Research, 32/1, 245-250.

[35] Skinner, D. J. (1997). Earnings disclosures and stockholder lawsuits. Journal of Accounting and Economics, 23/3, 249-282.

[36] Solomon, J.F.; Solomon, A.; Norton, S.D. and Josef, N.L. (2000). A conceptual framework for corporate risk disclosure emerging from the agenda for corporate governance reforms. British Accounting Review, 32/4, 447-478.

[37] Thornton, D. B., \& Welker, M. (2004). The effect of oil and gas producers' FRR No. 48 disclosures on investors' risk assessments. Journal of Accounting, Auditing and Finance,19/1, 85-114.

[38] Tsakumis, G.T., Doupnik, T.S. and Seese, L.P. (2006). Competitive harm and geographic area disclosure under SFAS 131. Journal of International Accounting, Auditing and Taxation, 15/1, 32-47.

[39] Turnbull Report, (1999). Internal control: Guidance for directors on the combined code, The Institute of Chartered Accountants in England \& Wales, London.

[40] Venkatachalam, M. (1996). Value-relevance of hanks' derivative disclosures. Journal of Accounting and Economics, 22/, 327-355.

[41] Woods, M., Reber, B., (2003). A comparison of UK and German reporting practice in respect of disclosure post GAS 5 . Unpublished conference paper, 6th Financial Reporting and Business Communication Conference, Cardiff Business School, Cardiff. 